\title{
Jwaneng - the untold story of the discovery of the world's richest diamond mine
}

\author{
by N. Lock*
}

\section{Synopsis}

Despite the pre-eminence of the Jwaneng Diamond Mine as the world's richest diamond mine, the discovery story has long been clouded in mystery. This is the 45-year old untold story of the Jwaneng discovery and contemporaneous Bechuanaland/Botswana political and socioeconomic history. Diamond exploration by De Beers in Bechuanaland began in 1955, with the first true kimberlite discovery near Letlhakane in 1967, before Clifford's Rule was applied and before the use of indicator mineral chemistry. Surface deflation soil sampling and bioturbation by termites was the foundation for exploration into the Kalahari. The 1962 reconnaissance programme south of Jwaneng had failed to make any discoveries. Improved sampling methods were applied to the Kalaharicovered areas in 1969 and positive results were received by year-end. The Whateley's Wish percussion drill-hole in December 1972 was confirmed as Jwaneng 2424D/K2 with drill core in early 1973 . Jumper drills were required to penetrate the Kalahari sand cover. Diamond resources were demonstrated despite multiple technical problems.

Keywords

Botswana, Jwaneng, kimberlite, diamond, discovery.

\section{Introduction}

The Jwaneng Diamond Mine is, by value, the world's richest diamond mine. Harry Oppenheimer is quoted as saying that Jwaneng is 'the most important primary deposit found anywhere in the world since the discovery at Kimberley more than a century ago.' (Taylor III, 1982) The mine opened in 1982 after some nine years of evaluation and construction since discovery in February 1973. Debswana (2017) states that 2015 production was 7.87 Mt of ore from which 10.408 million carats were recovered at a grade of 132 carats per $100 \mathrm{t}$ (cpht). Although the value is not reported, it was noted that Jwaneng contributes $60-70 \%$ of Debswana's total revenue from all mines, including Orapa, Damtshaa, and Letlhakane (Debswana, 2017).

Despite the value and economic preeminence of Jwaneng, the discovery story has long been clouded in mystery. In 1967, Orapa was front-page news in the South African press shortly after the discovery, with the discovery geological team receiving personal praise and interviews. In contrast, it was not until many years after its discovery that Jwaneng was the subject of praise from Harry Oppenheimer. The discovery, which spanned some five years from 1969 to 1973, has never received the same publicity as Orapa.

This paper will trace the background events and the Botswana political and socioeconomic history leading to the untold story of the drilling of the Whateley's Wish discovery percussion drill-hole in December 1972, with drill core confirmation of Jwaneng 2424D/K2 in early 1973.

The discovery presented another conundrum because of the $45 \mathrm{~m}$ cover of Kalahari sediments that made thenconventional evaluation techniques ineffective. Evaluation proceeded by large-diameter drilling (LDD). The first ever threedimensional diamond resource demonstrated economic viability for mine development, despite the multiple technical problems and complex parameters that required integration to achieve a reasonable level of confidence.

\section{The political and economic context}

The Bechuanaland Protectorate has a central place in African colonial history, not least because the territory straddled the route of Cecil Rhodes' projected Cape to Cairo railroad. He said 'I look upon this Bechuanaland territory as the Suez Canal of the trade of this country, the key of its road to the interior ...' (Keppler-Jones, 1983). The so-called 'Missionaries Road' crossed the Protectorate

* Retired, Private Consulting Geologist, South Africa.

(C) The Southern African Institute of Mining and Metallurgy, 2019. ISSN 2225-6253. This paper was first presented at the Diamonds - Source to Use 2018 Conference, 11-13 June 2018, Birchwood Hotel and OR Tambo Conference Centre, JetPark, Johannesburg, South Africa. 


\section{Jwaneng - the untold story of the discovery of the world's richest diamond mine}

from south to north, and the Batswana Dikgosi (chiefs) strengthened their relationship with the missionaries as a defense against the expansionist machinations of Rhodes' British South Africa Charter Company. The representations of the revered three Dikgosi, when they visited London in 1895 to defend Tswana independence, and the disastrous Jameson Raid into the South African Republic in the same year, paved the way for what eventually became independent Botswana.

The failure of the Charter Company to consolidate control of the Protectorate at the end of the nineteenth century resulted in a long period of disinterest in development in the territory while attention was concentrated to the north and south. At this time Tshekedi Khama (the uncle of and regent for the future first Botswana President, Sir Seretse Khama) and the tribal elders believed 'mineral development should only come when the people could welcome these developments on their own terms' (Prain, 1981).

Traditional cattle ranching dominated tribal life and the country remained one of the poorest in the world. The Bechuanaland Protectorate government was very much of a laissez faire nature until British Prime Minister MacMillan's 'Winds of Change' speech that heralded the post-Second World War world of the 1960s. Even in the early 1960s, some members of the Bechuanaland European Advisory Council advocated the incorporation of the Protectorate into either Rhodesia (now Zimbabwe) or the Union of South Africa. Fortunately, the winds of change were blowing strongly and Bechuanaland moved towards independence with the establishment of political parties and progressed to self-government and parliamentary rule in 1965. Full independence followed as the Republic of Botswana with Sir Seretse Khama as the first President on 30 September 1966. Although Botswana was expected to require British government grant-in-aid for the foreseeable future, fiscal prudence achieved a surplus before mineral revenue began to accrue in the early 1970s.

The opening of the Orapa diamond mine in 1971 was the first step on the road to the transformation of the Botswana economy and the rapid expansion of social services and national infrastructure. Investment has been made in schools and hospitals, roads and power, piped clean water to urban areas, and telecommunications benefiting from new technologies that leapfrog older landline links.

Janse (2007, compiled from sources listed in Table I) illustrated global diamond production by volume (millions of carats) since 1869, with the Orapa and Jwaneng production startup dates. It is notable that Botswana's contribution made a more marked global impact from 1982 when production from Jwaneng began. This fact is further demonstrated if production value is considered (Janse, 2007). Grateful as the country must have been for the new Orapa mine, the big step forward came from the Jwaneng mine. The much higher grade and value ensured the success of consecutive National Development Plans for socioeconomic investment.

\section{The evolution of mineral law and concessions}

Tshekedi Khama was Regent for the Bamangwato from 1926 to 1949 , and a strong political voice until his death in 1959 . It was his struggle, during the period 1929 to 1932 with the British South Africa Charter Company and the British
Protectorate Administration before the first Mines and Minerals Proclamation of 1932, which ensured that Botswana's mineral wealth was preserved for the people of Botswana (Crowder, 1985).

Tshekedi Khama and Sir Ronald Prain, Chairman of Rhodesian Selection Trust, met for lunch in London in the mid-1950s (Prain, 1981). After lunch they discussed the outline for what became the last mineral concession in Bechuanaland under pre-independence mineral law, and the road to the evaluation and development of the Selebi-Phikwe $\mathrm{Ni}-\mathrm{Cu}$ mine. This relationship also included consideration for diamond exploration and the Consolidated African Selection Trust Ltd (CAST) Crown Grant to explore for diamonds across the eastern part of the Bamangwato Tribal Territory. It was this CAST concession that recovered the first diamonds from the Motloutse River near Foley in northeast Bechuanaland in 1959 (Willis, 1960).

The agreement was only finally signed when Tshekedi Khama lay on his deathbed in London. His goal to preserve and protect mineral development for the Batswana was secured. The machinations of Europeans, Cecil Rhodes and his British South Africa Charter Company, and elements of the British Protectorate Administration were largely defeated, but that is another story (see Crowder, 1985; Lock, 1988).

\section{The first kimberlite discovery at Letlhakane}

Serious diamond exploration by De Beers began in 1955, but it was another decade before kimberlite discoveries were made in the Letlhakane village area. Along the way it is clear that corporate patience was tested, the targeting strategy evolved, and sampling and processing methods were transformed.

De Beers followed up the CAST work in 1962 and was able to duplicate the results. It is possible that De Beers' exploration effort could have died through corporate lethargy but for an idea first expressed by CAST (Willis, 1960). While the official CAST conclusion, a basal Karoo conglomerate origin for the diamonds, may have been directed by corporate pressure, Willis also recognized the possible effects of crustal warping on the Motloutse drainage as envisaged by Lester King in his classic book, South African Scenery: A Textbook of Geomorphology. published in 1943. Dr Gavin Lamont, who was the Country Manager for Kimberlitic Searches, subsequently De Beers Botswana Prospecting, from 1955 until his retirement in 1979, independently came to the same conclusion (Lamont, 2011) through consideration of Alex du Toit's Kalahari-Rhodesia Axis (du Toit, 1933), but he also read the CAST report (Lamont, 2001; Lock, 2012).

De Beers' Consulting Geologist Arnold Waters was persuaded by Dr Lamont in 1964 to test this theory. A road reconnaissance sampling programme over the watershed to the west into the Letlhakane area was eventually undertaken in 1966. This was a seminal moment in the Botswana diamond story as Waters' patience had been tried and almost exhausted. The immediate recovery of kimberlitic garnets and ilmenite quickly led to the discovery of kimberlites $2125 \mathrm{~B} / \mathrm{K} 1$ north of Letlhakane village and 2125A/K1 west of Letlhakane village near a cattle post named Orapa in March and April 1967 respectively. 


\section{Jwaneng - the untold story of the discovery of the world's richest diamond mine}

\section{Exploration philosophy and sampling techniques}

Tom Clifford was the senior lecturer in metamorphic petrology at Leeds University in the 1960s and early 1970s at the time of the Research Institute of African Geology, partfunded by Anglo American Corporation, and during the author's time as an undergraduate there. Figure 4 in Clifford (1966) empirically supports the association of diamondiferous kimberlites with cratons stable since $1500 \mathrm{Ma}$. Although Clifford had nothing to do with the naming of this observation, it has been adopted as Clifford's Rule in the diamond industry. Clifford's Rule still stands the test of time, but was never explicitly applied in the Bechuanaland and early Botswana exploration.

The largest portion of Botswana is Kalahari Desert (Carney, Aldiss, and Lock, 1994). Only in the east is traditional geological mapping possible. The Kalahari Group in Botswana is preserved as a sequence of early fluvial sediments and later aeolian deposits. It contains remnants of landforms from both wetter and drier periods. The current sand surface is variously vegetated with grass and scrubland, and sporadic trees.

Although only limited geological mapping had been undertaken in Botswana pre-independence, the occurrence of ancient Archaean basement rocks in the countries surrounding Botswana was well documented and the extension of most of these rocks into Botswana was also known. A new geological map of Botswana was published in 1973 (Jones, 1973; Figure 1). Geophysical studies (e.g. Reeves and Hutchins, 1976; Terra Surveys Limited, 1978) have provided much knowledge and detail as to how these geological terrains come together under the Kalahari and
Karoo sequences of central Botswana. With hindsight, it is thus possible to conclude that much of the early De Beers diamond exploration fortuitously targeted potentially diamondiferous cratonic terrain.

Also, detailed mineral chemistry analysis in diamond exploration had not yet begun in the mid-1960s; the now famous G10 garnet was only defined in 1975 (Dawson and Stephens, 1975). Observation of garnet colour usually allowed discrimination of metamorphic from magmatic/mantle garnets. The metallic lustre on conchoidal fracture surfaces is a distinguishing feature of picro-ilmenite.

Part of De Beers' success was the consequence of evolving sampling techniques. Early stream sediment sampling in eastern Bechuanaland was inappropriate in the Kalahari regions of the central and western parts of the country. Even in eastern Botswana stream development was poor and did not provide a uniform areal coverage.

Lamont (2001) wrote 'It is of interest to mention that in the Tuli Block in 1955 I devised the continuous scooping method of soil sampling to cover the interfluve areas between the drainage lines. When I demonstrated this new sampling method to Arnold Waters he was not particularly impressed and he called it "the lame duck method" because every ten to fifteen paces the man taking the samples stoops down to scoop up some soil. Anyway it was thanks to this soilsampling method that we eventually found Orapa and Letlhakane and then Jwaneng.' We can now appreciate that this was far from being a lame duck method!

Lamont (2001) critiqued the sample processing method thus: 'In 1962 Jim Gibson and Jim Platt were still using the gold pan to concentrate their soil-samples and that is

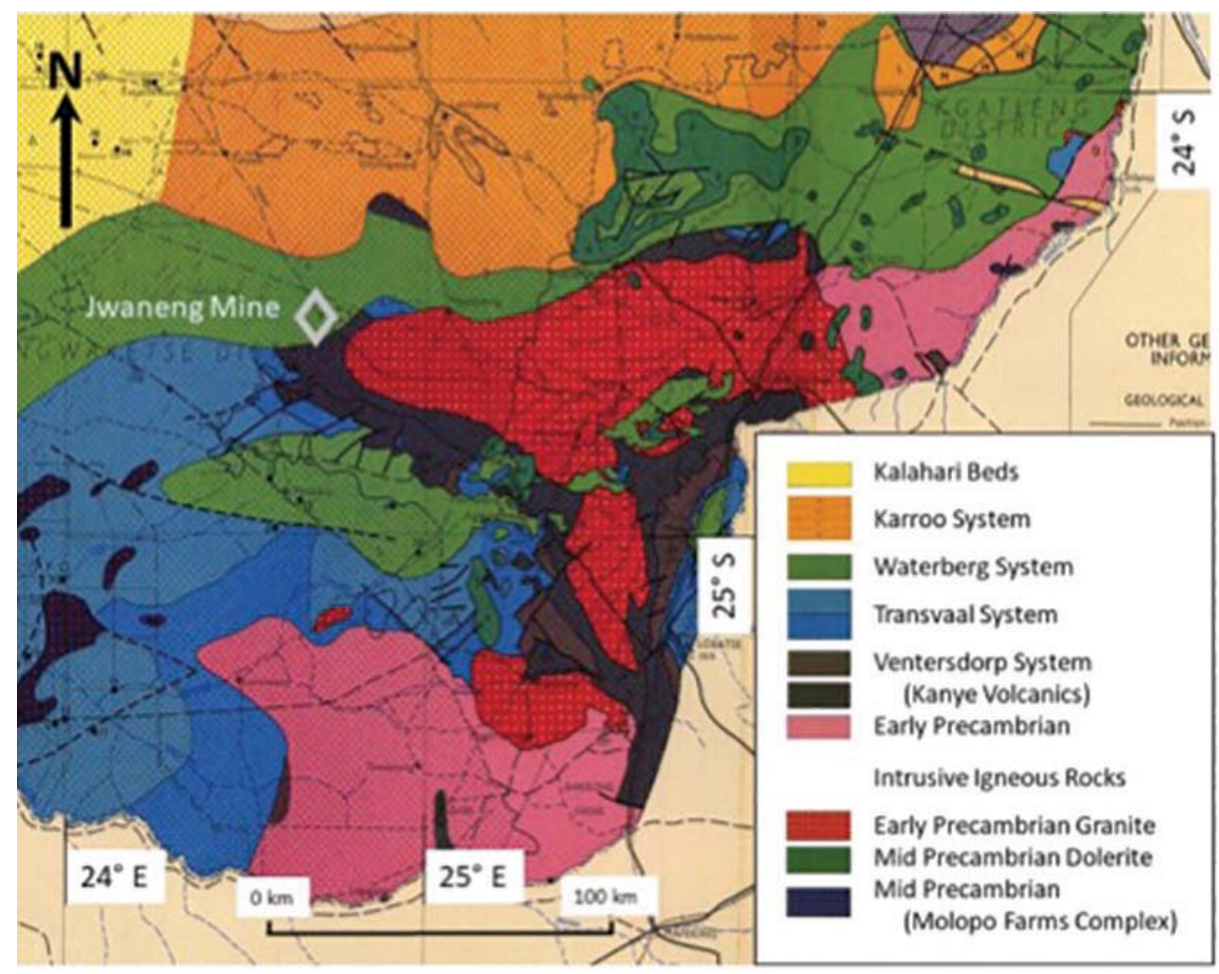

Figure 1-Geology of the Jwaneng area as known in 1973 (extract from the Geological Map of Botswana, Jones, 1973). Note that the edge of the Kalahari sand covered area is shown with a superimposed stipple 


\section{Jwaneng - the untold story of the discovery of the world's richest diamond mine}

certainly why they missed the 1 millimetre and smaller garnets from the Jwaneng pipes halo.' Gibson and Platt undertook this reconnaissance sampling along the Kanye to Ghanzi trans-Kalahari road; gold panning was discarded in favour of gravitating subsequent to this failed road reconnaissance and prior to the Letlhakane road reconnaissance in 1966.

De Wit (in press) has provided some detail on the change from gold pan concentrating to hand gravitating by shaking and rotating a screen under water, and the continuous scoop sampling technique developed by Lamont in Bechuanaland during the early 1960s.

Lamont (2001) correctly hypothesised that bioturbation by white ants (termites) would transport kimberlite indicator minerals (KIMs) to the surface in areas covered by Kalahari sediments. Bioturbation is the disturbance of loose soil or sedimentary deposits by living organisms and is not limited to activity by termites. However, it is termites' thirst for moisture that motivates their excavations down to the water table, with 'waste' including KIMs deposited at surface.

Lamont (2001) wrote 'Some years after I retired I paid a visit to Jwaneng and by that time the open pit was well developed. Around the sides of the pit the interface between the kimberlite and the overlying fifty metres of Kalahari sand and other sediments were (sic) exposed, and there we were able to see a few small fossil tunnels that had been made hundreds of thousands of years ago when the first miners at Jwaneng, the termites, burrowed down to get moist clay with which to build their large mounds at the surface; in bringing up moist clay from the kimberlite, they also brought up the small kimberlitic garnets and ilmenites, and it was these mineral grains that our soil-sampling programmes found and that led us to the Jwaneng pipe.'

In the early 1980s, similar termite tunnels in the underground sampling development drives at depths up to $150 \mathrm{~m}$ were observed by both the author and the project geologist, Stuart Vercoe.

The KIMs brought to surface are subject to concentration by rain and wind and natural deflation into a weak heavy mineral anomaly, especially around roots of grasses and shrubs that may provide windbreaks similar to trap-sites in stream sediment sampling. The deflation anomaly may well become weaker with increasing thickness of sand cover. It is probably important to comment that bioturbation is never a one-step process; it is incremental and cumulative over geological time. After the Jwaneng discovery it was possible to develop a profile through the Kalahari sediments. This demonstrated to Vercoe that there were at least three deflation surfaces; the oldest immediately on the eroded kimberlite surface, interpreted as the African Surface at about $60 \mathrm{Ma}$; and two further younger surfaces.

Reconnaissance soil sampling (RSS) was conducted on traverses at one mile $(1.6 \mathrm{~km})$ intervals (Figure 2), with subsamples along these lines allowing a preliminary graphic plot. Detailed soil sampling (DSS) was conducted over a reduced grid scale (quarter mile or $500 \mathrm{~m}$ ) collecting spot samples, with similar sample treatment and plotting as for RSS. Finally, detailed grid loaming (DGL) was undertaken over selected priority anomalous areas of limited extent at a grid spacing of $100 \mathrm{~m}$ or $50 \mathrm{~m}$. Grain count contour plots from
DGL were usually adequate for drill-hole targeting in the Orapa area.

Imperial grid dimensions (miles and yards) were changed to metric (kilometres and metres) in the Jwaneng area at the time of the duplicate sampling in late 1972, described below.

\section{The road to Jwaneng}

The Trans-Kalahari road in the 1960s and early 1970s was a broad double sand track maintained to enable the transport of cattle from the Ghanzi farms in the west to the Botswana Meat Commission export abattoir in Lobatse. During the summer rains it often became almost impassable for days at a time because the tracks were graded deeper and deeper during maintenance, with the rain converting these into pools or small lakes.

Lamont wrote 'I decided to try some soil-sampling on either side of the road that goes out from Lobatse to Ghanzi where the sand-cover is relatively thin. Jim Gibson and Jim Platt carried out this work but nothing of interest was found in their samples although they worked to within some twenty kilometres south of today's Jwaneng mine, and they certainly covered ground where there are small kimberlitic garnets in the "halo" of indicator minerals that surrounds the Jwaneng group of kimberlites. This was the first time that we had moved into the Kalahari environment and our sampling methods in those days could not cope. That is how we missed Jwaneng in 1962 ...' (Lamont, 2001).

De Beers had surmised that areas of the Kalahari with thin sand cover surround isolated bedrock outcrops. This observation and the changed sampling methods provided a locus for renewed exploration. Only after the Orapa discovery were the improved sampling and treatment techniques applied, moving west into the Kalahari in 1969. As with the 1966 Letlhakane area road reconnaissance, the first indications of the discovery to come were quickly demonstrated by laboratory results.

\section{Discovery in December 1972, and confirmation in early 1973}

A comprehensive Kalahari sampling programme commenced in early 1969. The author was involved in this programme as a field assistant/officer in the vicinity of Molepolole, before

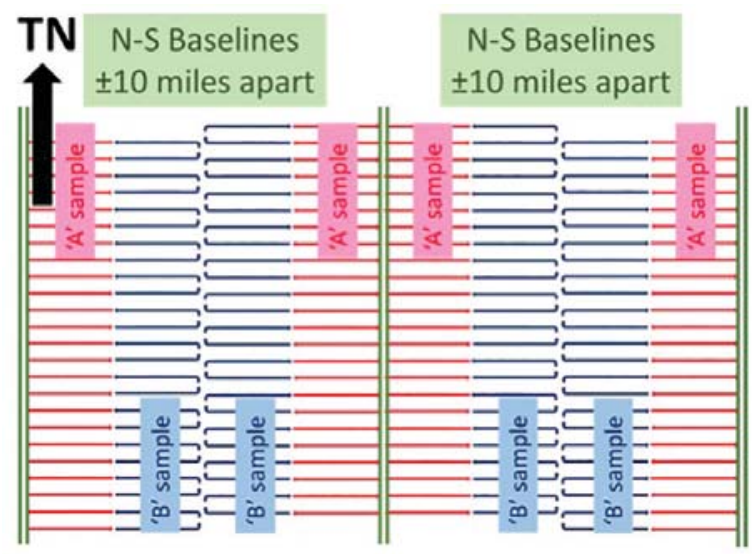

Figure 2-Schematic diagram of reconnaissance soil sampling 


\section{Jwaneng - the untold story of the discovery of the world's richest diamond mine}

leaving in July 1969 to study geology at Leeds University in the UK. A number of geologists were involved in this programme but it was the RSS work of Mike Whateley that produced the first signs of potential discovery. Table I shows the discovery timeline together with the individual geologists involved at each stage.

Lamont (2001) reported 'By the end of the third quarter of 1969 the Anglo American Research Laboratories reported the first definite and probable ilmenites from reconnaissance soil-samples taken over 150 square miles $\left(390 \mathrm{~km}^{2}\right)$ across the Kweneng/Ngwaketse boundary, and these ilmenites are therefore considered the first indication of the Jwaneng kimberlite province'.

RSS work continued over the whole licence area before anomalous areas were covered with DSS, and priority targets were sampled with DGL. The details of the phased programme results up to the end of 1971 (as with all the results discussed in this paper) are no longer available to the author but are illustrated in Figure 3, from Lock (1985), annotated with the eventual kimberlite numbers. The geologists also named the KIM targets, with 2424D/K1 and 2424D/K3 named Malan 1 and 2, 2424D/K2 named Whateley's Wish, and 2424D/K4 named Lynn's Luck. Whateley left the company in the first half of 1971 and thus missed the first kimberlite discovery in 1972.

1972 marked a seminal moment in the Jwaneng story. Peter Bickerstaff led a stepped-up programme that moved quickly from ground magnetics and gravity to drilling. The magnetic survey was undertaken using the cumbersome Scania vertical-field magnetometer that required levelling for each station reading. It was thus very slow but provided a good outline on which to plan a drilling campaign. A gravity survey displayed a similar-shaped anomaly.

A Holman tractor-mounted, down-the-hole hammer VOLE drill, first used at Orapa, was relocated to the southern Kalahari in early 1972. It was limited to 120 feet (37 m) depth, and it was thus not suitable for thick overburden areas. However the sand thickness was not specifically known until the first hole was drilled, although there was rock outcrop at Jwana Hill nearby and another rocky hill was visible on the skyline. Fortunately, 2424D/K1 did not have a thick sand cover and drilling intersected kimberlite within the drill's capability. A headgear used at Orapa was brought to site and two pits were sunk to $35 \mathrm{~m}$ depth to further prove the presence of kimberlite and recover small samples to test for diamond content.

Botswana Mining Law limited the depth of surface pitting/trenches to 120 feet $(37 \mathrm{~m})$. 2424D/K1 was shallow enough for this sampling method, which had been used at Orapa, but representative samples sent to the Diamond Research Laboratory in Johannesburg returned negative results.

Whateley's Wish (2424D/K2) was also drilled by Bickerstaff in 1972, but the drill limitation prevented further kimberlite discovery at this time; the hole or holes did not reach the base of the Kalahari. It was suggested that the holes may have been mislocated to the south of the anomaly.

These disappointments resulted in Bickerstaff being relocated to other projects while Lamont and the Stuart Vercoe reviewed all the results to date and developed a new

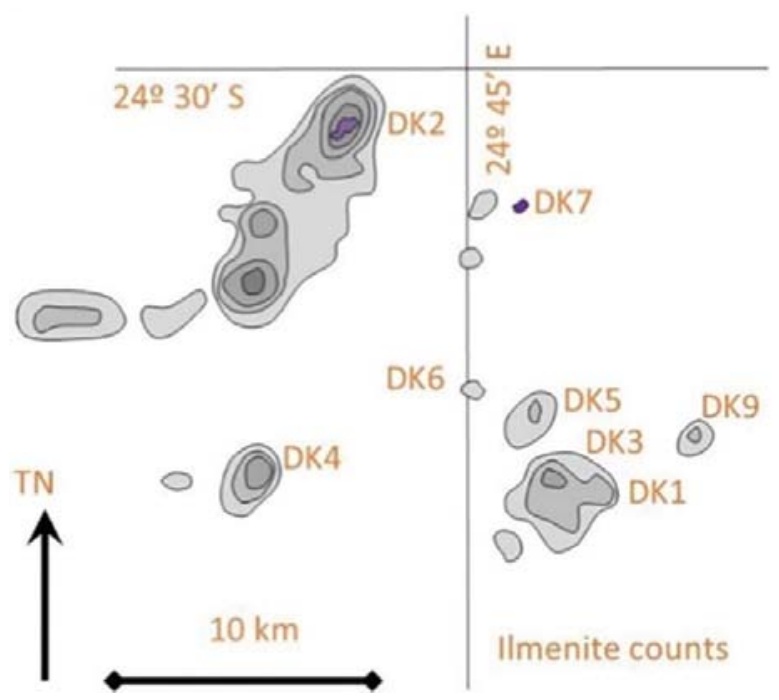

Figure 3-Plot of regional DSS ilmenite grain counts (Lock, 1985)

\section{Table I}

\section{Discovery timeline}

\begin{tabular}{|c|c|c|c|}
\hline Year & Activity & Geologist & Discovery \\
\hline 1962 & Road reconnaissance & Jim Gibson/Jim Platt & Barren samples \\
\hline 1963-1968 & No activity & & \\
\hline 1969 & Reconnaissance soil sampling & Mike Whateley/Keith Huxham and others & First KIM recoveries confirmed by DRL* \\
\hline 1970 & Detailed soil sampling & Whateley/Bruce Lynn & Progressive KIM spatial disbution results \\
\hline 1971 & Detailed grid loaming & Whateley/Lynn & Progressive KIM spatial distribution results \\
\hline 1972 & Ground magnetics and gravity/drilling & Peter Bickerstaff & 2424D/K1 - March 1972 \\
\hline $1972-1973$ & DSS/DGL/ground magnetics/drilling & Stuart Vercoe/Norman Lock & 2424D/K2 - December 1972 and into early 1973 \\
\hline 1974 & DGL/ground magnetics/drilling/airborne magnetics & Vercoe and others & 2424D/K4 \& 2424D/K3 \\
\hline 1975 & DGL/ground magnetics/drilling & Vercoe and others & 2424D/K5 \& 2424DK6 - Q3 \\
\hline 1976 & DGL/ground magnetics/drilling & Vercoe and others & 2424D/K7 - Q3 \\
\hline 1977 & DGL/ground magnetics/drilling & Vercoe and others & 2424D/K8 - Q2 \\
\hline
\end{tabular}




\section{Jwaneng - the untold story of the discovery of the world's richest diamond mine}

work plan for implementation from September 1972. This work plan required repeat DSS and DGL sampling on a new metric grid over Whateley's Wish (2424D/K2) and a repeat ground magnetic survey using the newly introduced Geometrics proton precession magnetometer.

Vercoe supervised the soil sampling, assisted by Moses Rapoo, and submitted sample concentrates to an onsite heavy liquid separation laboratory with KIM grain picking under a binocular microscope. The mineral recoveries were dominated by ilmenite, with a subordinate pyrope garnet component. Despite these favourable results, grid plotting did not result in a coherent contoured plot. This may have been due to surface disturbance by cattle from the local cattle post, and/or by the thousands of annually migrating hartebeest and wildebeest, as was feared by Lamont. This author devised simple moving average and root mean square algorithms to smooth of the erratic sample counts that sometimes jumped from low single digits to hundreds, and back again in adjacent samples (Lamont, 2001). This approach, entirely manual being before the advent of field computers, proved most efficacious with a fairly robust low domal feature being defined (Figure 4).

The proton magnetometer survey was carried out by this author, assisted by Tabona Machinye. This early Geometrics model was entirely manual with readings recorded on paper and all levelling carried out back in camp in the evening. A $50 \mathrm{~m} \times 50 \mathrm{~m}$ grid provided corrected readings for contouring at 5- and 10-gamma intervals. The result was a weak domal anomaly (Figure 5) that coincided well with the smoothed ilmenite plot.

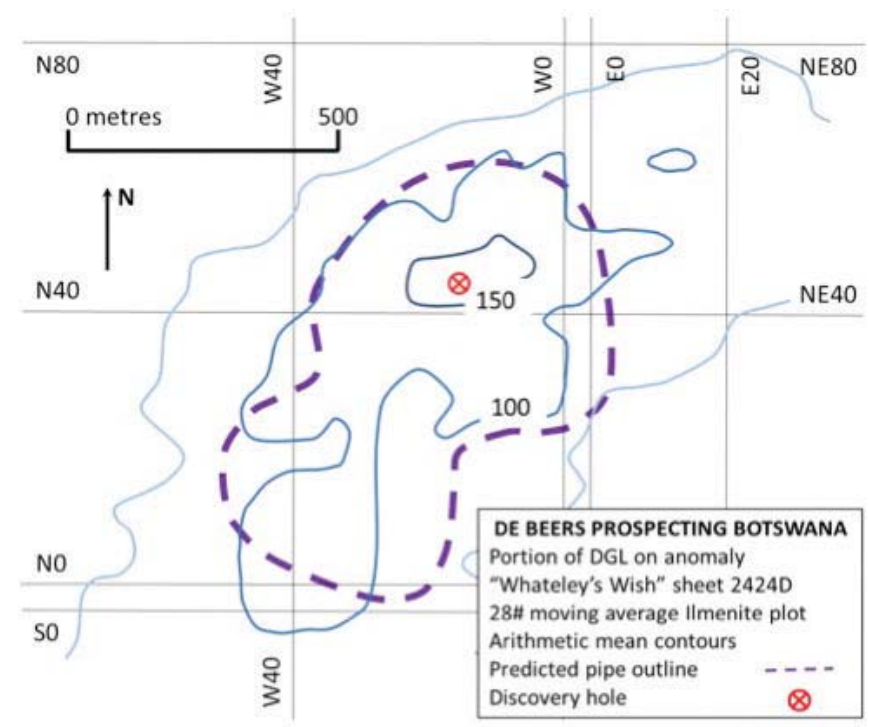

Figure 4-Moving average contour plot of ilmenite grain counts (+28\#) for Whateley's Wish (redrawn from the original map, with discovery hole and predicted pipe outline added)

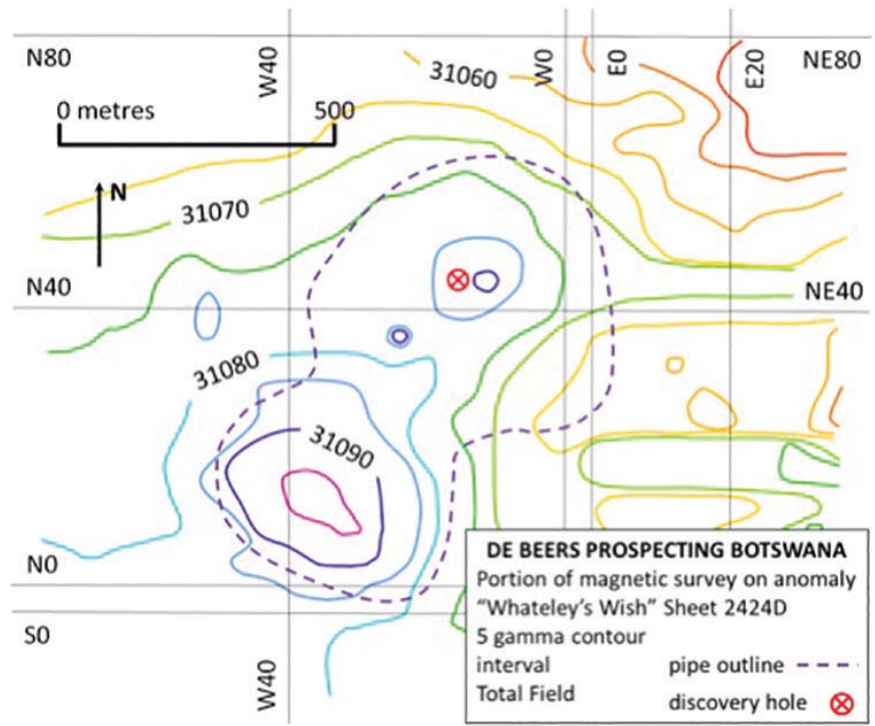

Figure 5-Geometrics proton precession magnetometer survey of Whateley's Wish (redrawn from the original map with discovery hole and predicted pipe outline added) 


\section{Jwaneng - the untold story of the discovery of the world's richest diamond mine}

Target selection for a new drilling campaign was now possible with reasonable confidence of success.

It is worthy of note that when an aeromagnetic survey was undertaken in 1974, 2424D/K1 showed a weak but well defined magnetic high whereas 2424D/K2 displayed only a broad weak domal high that may not have been selected as a priority without the supporting sample results.

The first new drill target, N44/12, returned suspected kimberlite at 138 feet depth at 11 am on 16 December 1972 (Lock, 1972, Figure 6).

Although the drill chips were very fine pink clayey material with no recognizable texture, the presence of abundant KIMs was sufficient evidence for Murray (1973a) to report 'One hole went into what is thought to be kimberlite ...' The drill chip samples were concentrated using a simple hand-operated Gerryts jig that had been designed by Bert Gerryts in the 1950s as a substitute for other methods of concentrating loam samples. A further four holes logged by this author intersected kimberlite over the next seven weeks.

Core drilling in early 1973 (Murray, 1973b, 1973c) provided rock samples from below the Kalahari-kimberlite interface, although official confirmation awaited a 1974 petrology report by Clement (1974). The discovery was officially recognized as $2424 \mathrm{D} / \mathrm{K} 2$ in the second quarter of 1973 (Murray, 1973c), in line with the De Beers scheme of that time, but the name 'Whateley's Wish' persists informally with those involved. By the third quarter of 1973 enough drilling had been undertaken for the Jwaneng 2424D/K2 kimberlite to be reported (Murray, 1973d) as '... an oval shape approximately $850 \mathrm{~m}$ long by $350 \mathrm{~m}$ to $400 \mathrm{~m}$ wide.'

Clement (1974) reported that '... preliminary examination indicates quite clearly that the pipe is, at least in part, overlain by kimberlitic sediments and/or kimberlitic tuffs.' This description is broadly consistent with modern terminology in Webb, Stiefenhofer, and Field (2003) who note '... two contrasting textural types of kimberlite, which have been interpreted as (a) resedimented volcaniclastic kimberlite and (b) dark pyroclastic kimberlite.'

The challenge of using this underpowered drill was underlined when, a few holes after the discovery, the whole drill string was lost, at great expense.

\section{Evaluation challenges and economic viability}

The Naledi valley is a broad very shallow grass-covered paleo-valley. A small rural community was domiciled around the low Jwana Hill, where a single water borehole sustained the cattle post and helped De Beers in the early days of exploration.

Lamont (2001) wrote 'Stuart then took over the drilling programme around Norman's kimberlite intersection, and as the pipe got bigger and bigger we knew we were really onto something significant.' (N.B. this refers to Norman Lock's intersection of the 2424D/K2 kimberlite in drill-hole N44/12, Figure 6). Lamont continued 'It was clear that we needed much heavier drilling equipment to cope with the Kalahari sand-cover, and I thought about the percussion "jumper"

“ DE BEERS PROSPECTING - BOTSYIANA. AIR DRILL LOG.

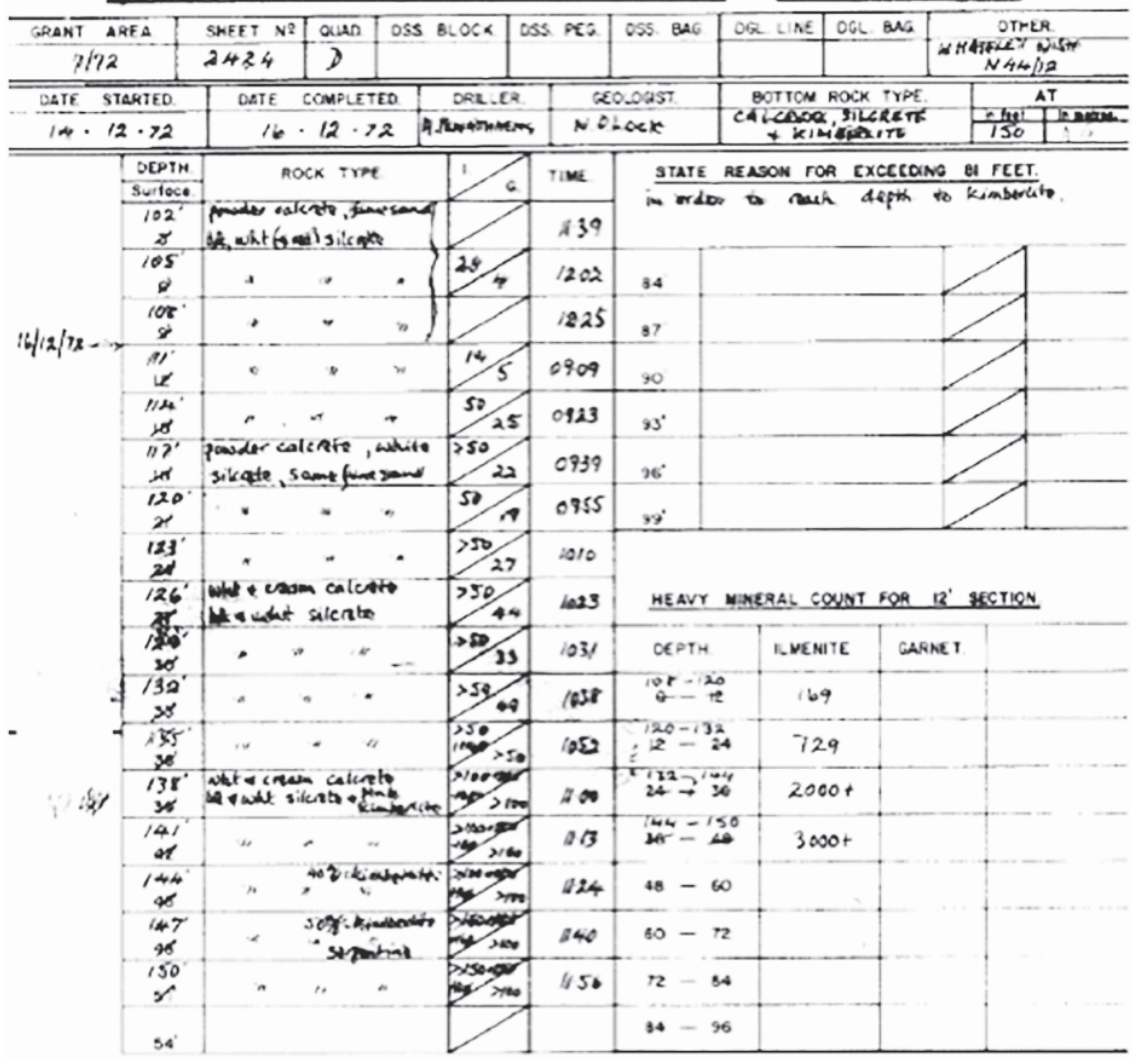




\section{Jwaneng - the untold story of the discovery of the world's richest diamond mine}

drills that Jim Gibson and I had used in the early days at Orapa to drill the first water-supply boreholes.' The standard jumper drill bit for water boreholes was $4 \frac{1}{2} 2$ inches $(114 \mathrm{~mm})$, but specialized bits for this and future sampling programmes were progressively increased in size to 24 inch $(610 \mathrm{~mm})$.

Initial outline drilling of the 2424D/K2 kimberlite was supervised by Vercoe using the VOLE drill. A series of holes was drilled along the assumed northeast-trending long axis of the kimberlite at $100 \mathrm{~m}$ intervals, controlled by KIM and magnetic data. The dimensions of the South and Central Lobes of the tri-lobate Jwaneng pipe were of the order of $900 \mathrm{~m}$ by $500 \mathrm{~m}$. A great deal of difficulty was experienced using this depth- and power-limited drill in penetrating the Kalahari overburden.

Six water bores to replace the village supply were sunk around the margins of the pipe using a jumper drill (cable tool drilling rig) with the first hole providing 1200 gallons per hour or $546 \mathrm{~L} / \mathrm{h}$ containing $1200 \mathrm{ppm}$ total dissolved solids (TDS).

The rig was then used, with other jumper drills, drilling 6-inch $(152 \mathrm{~mm})$ diameter holes to further delineate the kimberlite. The jumper drills used had the advantage of:

$>$ The low cost per metre

- A simple construction, low cost, and ease of maintenance and repair

> A larger sample from the 6-inch $(152 \mathrm{~mm})$ or 8-inch (203 $\mathrm{mm}$ ) hole size compared to the VOLE drill.

The disadvantage was the slow penetration rate of approximately10 m per 8-hour shift compared to the VOLE drill.

The holes were cleaned of drill cuttings and water by a dart or flap valve bailer into half-drums in one-metre sections. Dried kimberlite samples were shipped to the Anglo American Research Laboratory/Diamond Research Laboratory in Johannesburg.

\section{Evaluation drilling}

It was not possible to sink shallow prospecting shafts, as had been done at Orapa. Preliminary evaluation therefore used the jumper drill with strengthened 15-inch (381 mm) chisel bits. The initial thirty holes of 15 inch $(381 \mathrm{~mm})$ diameter were drilled at $100 \mathrm{~m}$ line spacing and $200 \mathrm{~m}$ hole spacing to $150 \mathrm{~m}$ depth.

Potentially significant economic grades were demonstrated despite the spatial inhomogeneity of grade. Underground bulk sampling was rejected by the Botswana Government, which favoured continued large-diameter jumper drilling despite a number of data integrity issues. Diamond recoveries showed that the Central Lobe was the richest area and the South Lobe less so. There was very poor grade correlation between sampling drill-holes. No sampling data for the North East Lobe was available from this initial programme.

Closer spaced sampling data was required with holes drilled on a $100 \mathrm{~m}$ sampling grid to $200 \mathrm{~m}$ depth and finally at $50 \mathrm{~m}$ centres, also encompassing the North East Lobe. Drill sampling by jumper drills was completed in 1982. Poor horizontal and vertical grade correlations and other issues listed below persisted.

\section{Sample processing}

Five-metre drill samples averaged $1.5 \mathrm{t}$, computed from caliper logging and density. Caliper logs showed break-back and contamination of lower levels by the less competent upper tuffaceous pyroclastic/debris flow horizons.

The 2424D/K2 15-inch (381 mm) jumper drill sample sludge was classified into three fractions $(0.5-1.5 \mathrm{~mm} ; 1.5-$ $4 \mathrm{~mm}$; >4 mm) using Sweco screens. Samples were dried and weighed. Density by water displacement was only a first approximation of the true bulk density. The two smaller size fractions were concentrated by Pleitz jigging and then combined for milling with neoprene-lined mills using ceramic balls. The $>4 \mathrm{~mm}$ fraction was transferred directly for milling separately. Milling was required for pre-conditioning prior to diamond recovery over grease. Hand sorting was conducted on site.

Over 200 holes were drilled, producing $5000 \mathrm{t}$ of kimberlite. The work resulted in the delineation of about $90 \mathrm{Mm}^{3}$ of kimberlite for the 54 ha surface area. The sampling data at Jwaneng was down to $0.5 \mathrm{~mm}$ diamond size and thus overlapped with the typical microdiamond sample size range. However, factorization to larger bottom cut-offs was undertaken for practical production purposes.

\section{Further test work and resource estimation}

From the beginning of 1978, samples were obtained from shafts, three in the Central Lobe, two in the South Lobe, and one in the North East Lobe. This bulk sampling provided material for:

> Metallurgical test work

> Geology and emplacement model concepts

> Comparisons of diamond release from shaft and drive samples with that of highly comminuted drill slurry. For this latter purpose three 15-inch holes to $200 \mathrm{~m}$ were drilled around each shaft

> Collection of a larger diamond parcel for valuation. Initially, the material was treated in rotary pans (for shafts 1-4) with final recovery by jigging, milling, and grease recovery. Once the bulk sample plant was completed and commissioned, material from shafts 5 and 6 was treated by conventional DMS and X-ray recovery. From selected horizons, 20-t samples were sent to DRL for metallurgical test work.

Mineral resource estimation using ordinary kriging was undertaken in Kimberley. This was the first time that De Beers had cumulated a sample database to support a full three-dimensional resource estimate.

The estimation challenges at Jwaneng, which required several adjustments, included:

> Sample size

> Downhole break-back contamination

> Shafts not representative of the whole orebody

> Differences in treatment methods and efficiencies between jigging/grease recovery and rotary pans/DMS/X-ray

> Possible diamond breakage by drilling

> Density variations with depth

> Main Treatment Plant crushing to $25 \mathrm{~mm}$ rather than $12 \mathrm{~mm}$ used to feed rotary pans, and intense comminution of drill samples 


\section{Jwaneng - the untold story of the discovery of the world's richest diamond mine}

> Main Treatment Plant lower cut-off of $1.65 \mathrm{~mm} \mathrm{vs}$ $0.5 \mathrm{~mm}$ for drill samples and rotary pans

> Poor understanding of the orebody geology and emplacement mechanism

> Diamond security could also have been better.

The results supported a very positive outcome and the decision in 1978 to build a mine.

\section{Discussion and conclusions}

There are a number of little-known or unknown facts and opinions surrounding the Jwaneng story from the 1960s and 1970s, and beyond, that deserve mention.

Lamont commented on how different history might have been if Jwaneng had been found in 1962, before Orapa. There is no indication what thoughts may have been in Lamont's mind, but the following two points would surely have had significant possible consequences if the Jwaneng kimberlite had been found in 1962:

> Pre-independence Bechuanaland was a very different place to the Independent country we know today.

$>$ One of the first post-independence Acts of Parliament was the Mineral Rights in Tribal Territories Act, under which the various tribes voluntarily ceded their ownership of mineral rights to the new state of Botswana. This simple act of cession has allowed Botswana to avoid the challenges of many African and other countries worldwide in the post-independence era.

The implications of different decisions with regard to these points are left to the opinion of the reader, with perhaps the thought that any consequences could well have been highly detrimental for the future of the country.

De Beers and Debswana record the Jwaneng discovery as being in 1972, whereas the Jwaneng 2424D/K2 kimberlite was arguably properly confirmed with drill core only in early 1973.

2424D/K1 had been found the previous year, 1972, but there was a hiatus in exploration while the challenge of the thickness of the Kalahari sand cover was considered. In contrast with Orapa, there is a diversity of reporting of the Jwaneng discovery; the following examples are provided:

> In his discussion of the Debswana Joint Venture, $\mathrm{Mr}$ Blackie Marole (1988) stated 'Shortly after the establishment of the Letlhakane Mine, a further diamond bearing pipe was discovered at Jwaneng.' In reality, the Letlhakane Mine was established in 1975, some two years after the Jwaneng discovery.

> An important worldwide catalogue of kimberlite occurrences (Janse and Sheahan, 1995) strangely reports 1975 as the discovery year (as did Marole, see above).

> At least two well-known books about diamonds provide the historically accurate discovery date of 1973 (Bruton, 1979; Wannenburg and Johnson, 1990).

> Three books (Brook, 2012, 2016a, 2016b) report discovery dates of 1971 and 1973, 1971, and only the date of mine opening in 1982, respectively.

Lock (1985) published the distinction between the 2424D/K1 discovery in 1972 and the 2424D/K2 discovery in 1973, although in hindsight both may reasonably be recorded for the year 1972. Subsequently, Botswana Geological Survey Bulletin 37 (Carney, Aldiss, and Lock, 1994, p. 94) contained a similar statement of the Jwaneng discovery history. This publication should have authority as the definitive historic statement, but any new edition should amend the dates consistent with this paper.

It is fair to say that market pressures were developing during the 1970s with new and increased production from Orapa, and the Argyle project development, after its 1979 discovery, moving ahead in parallel with the Jwaneng evaluation (see Figure 2 in Janse, 2007). Notwithstanding these pressures, the Jwaneng Mine opened at the start of a dramatic upturn in the market through the 1980s and was sustained, even with new Canadian and additional Russian production, until the global financial crisis in 2008. Whatever impact these pressures may have exerted on the market and De Beers, the Botswana government held rather different development objectives. The very high Jwaneng profit margin would always have sheltered Botswana from the impact of a market squeeze. Indeed, during the 1980s Debswana accumulated its own stockpile to protect local employment. This stockpile was used in 1987 to purchase a 5\% interest in De Beers Consolidated Mines (Marole, 1988, Masire, 2006).

Perhaps history will link the parallelism of events following the Orapa Mine opening in 1971. With the timeline to the opening of the Letlhakane Mine, ongoing negotiations reviewing the Debswana Joint Venture concluded in 1975 with a revised 50/50 equity relationship (Marole, 1988; Masire 2006). President Masire commented in his autobiography (Masire, 2006) that 'In 1976, only a year after we had finalised the new agreement for the 50/50 partnership, De Beers came to tell us that they had found another payable deposit. It was Jwaneng, 80 kilometres west of Kanye in Ngwaketse.' There were clear differences and difficulties in the negotiations between the joint venture partners expressed by President Masire that can perhaps be summed up in his conclusion (Masire, 2006) that '... De Beers knew more about the potential than we did, so we were at a disadvantage in discussing the terms of an agreement that would be fair to both sides.'

As noted in the introduction, Jwaneng is Debswana's and the world's richest diamond mine. Published future mine planning for Jwaneng Cuts 8 and 9 will extend the open pit to some $850 \mathrm{~m}$ below surface over the next 20 years. It is not inconceivable that Debswana will still be mining Jwaneng well after 2050 and it is reasonable to predict a future underground mine to perhaps $1000 \mathrm{~m}$ depth or more, with the life of mine exceeding a century since discovery or even mine opening.

Stuart Vercoe and I have always emphasised the team effort that, in the words of Isaac Newton, allowed us to 'see farther by standing on the shoulders of giants.' Dr Lamont's memoirs make clear the contributions of several geologists over a number of years, from the early work of Mike Whateley in 1969 to the discovery drill-holes in 1972/3 and beyond (see discovery timeline in Table I). Fairly apportioning credit among the many geologists, and others who worked on the project, would have been problematic, though the discovery drill-hole marks a point in time. This paper can hopefully stand as a definitive factual historic record. 


\section{Jwaneng - the untold story of the discovery of the world's richest diamond mine}

\section{Acknowledgements}

Stuart Vercoe was the project geologist at the time of the discovery that was shared with the author here. His contribution in the form of personal communication, documents, and photographs has been very important to the completeness of this story; full credit is given here to his input even though he left preparation of the manuscript to this author.

I wish to thank the De Beers Group for permission to access original maps and reports relating to the Jwaneng discovery in their archives, and to present the information in this publication. In particular I am very grateful to the peer reviewer who in 2018 first drew attention to my deficient memory of the timing of events some 45 years ago, and facilitated this permission and access.

\section{References}

ВRоoк, M.C. 2012. Botswana's Diamonds - Prospecting to Jewellery. Selfpublished. 286 p.

ВRоoк, M.C. 2016a. Botswana Diamond Jewellery. Self-published. 136 p.

ВRоoк, M.C. 2016b. Botswana. 50 Years of Growth. Self-published. 81 p.

CARneY, J.N., Aldiss, D.T., and Lock, N.P. 1994. The geology of Botswana. Bulletin 37. Geological Survey of Botswana. 113 p.

Clement, C.R. 1974. Preliminary notes on core specimens from Jwaneng, Botswana. De Beers Consolidated Mines Limited, Geology Department. $7 \mathrm{p}$.

CLIFFoRd, T.N. 1966. Tectono-metallogenic units and metallogenic provinces of Africa. Earth and Planetary Science. Letters, vol. 1. pp. 421-434.

Crowder, M. 1985. Tshekedi Khama and mining in Botswana. 1929-1959. African Studies Seminar Paper. African Studies Institute, University of the Witwatersrand. $23 \mathrm{p}$.

Dawson, J.B. and Stephens, W.E. 1975. Statistical classification of garnets from kimberlite and associated xenoliths. Journal of Geology, vol. 83, no. 5. pp. 589-607.

De BeERS Group. 2017. Jwaneng Mine. http://www.debeersgroup.com/en/ourstory/our-history.html\#1960

DEBSWANA. 2017. Jwaneng Mine. http://www.debswana.com/Operations/Pages/ Jwaneng-Mine.aspx

DE WIT, M.C.J. 2018. Prospecting history leading to the discovery of Botswana's diamond mines: from artefacts to Lesedi La Rona. Proceedings of the 11th International Kimberlite Conference, Gaborone, Botswana (in press).

Du TorT, A.L. 1933. Crustal movement as a factor in the geographical evolution of South Africa. South African Geographical Journal, vol. XVI. pp. 3-19.

GuRney, J.J and Switzer, G.S. 1973. The discovery of garnets closely related to diamonds in the Finsch Pipe, South Africa. Contributions to Mineralogy and Petrology, vol. 39, no. 2. pp. 103-116.

JANSE, A.J.A. 2007. Global rough diamond production since 1870. Gems \& Gemology, vol. 43, no. 2. pp. 98-119.

JANSE, A.J.A. and SHEAHAn, P.A. 1995. Catalogue of world wide diamond and kimberlite occurrences: a selective and annotative approach. Journal of Geochemical Exploration, vol. 53. pp. 53-111.

Jones, C.R. 1973. Geological map of Botswana. 1:1 000000 scale. Geological Survey and Mines Department.
Keppler-Jones, A. 1983. Rhodes and Rhodesia. The White Conquest of Zimbabwe. 1884-1902. McGill-Queens University Press, Kingston and Montreal. $427 \mathrm{p}$.

LAMonT, G.T. 2001. My Memoirs. Unpublished.

Lamont, G.T. 2011. The quest for diamonds in the Bechuanaland Protectorate and Botswana. Prospecting in Africa. De Wit, M.C.J., Köstlin, E.O., and Liddle, R.S. (eds). De Beers Consolidated Mines Limited. pp. 171-202.

Lock, N.P. 1972. De Beers Prospecting - Botswana. air drill log N44/12.

Lock, N.P. 1985. Kimberlite exploration in the Kalahari region of southern Botswana with emphasis on the Jwaneng kimberlite province. Proceedings of Prospecting in Areas of Desert Terrain, Rabat, Morocco 1985. Institution of Mining and Metallurgy, London. pp. 183-190.

Lock, N.P. 1988. A history of mineral rights, ownership and law in Botswana. Proceedings of a Seminar on Mineral Policy in Botswana. Special Publication no. 1. Botswana Geoscientists. Association. pp. 5-15.

Lock, N.P. 2012. Orapa Mine: the role played by CAST geologists in its discovery. Letter to Geological Society of South Africa. Geobulletin, vol. 55 , no. 3 .

MASIRE, Q.K.T. 2006. Very Brave or Very Foolish. Memoirs of an African Democrat. Lewis Jr, S.J. (ed.). Macmillan Botswana. 358 p.

Marole, B. 1988. Debswana Joint Venture; a case study. Proceedings of a Seminar on Mineral Policy in Botswana. Special Publication no. 1. Botswana Geoscientists. Association. pp. 26-29.

MurRAY, L.G. 1973a. Quarterly report, State Grant 7/72, Ngwaketsi District. Report on prospecting activities for the period 1st October to 31st December 1972. De Beers Prospecting Botswana (Pty) Limited. p. 1.

MURRAY, L.G. 1973b. Quarterly report, State Grant 7/72, Ngwaketsi District. Report on prospecting activities for the period 1st January to 31st March 1973. De Beers Prospecting Botswana (Pty) Limited. p. 2.

MURRAY, L.G. 1973c. Quarterly report, State Grant 7/72, Ngwaketsi District. Report on prospecting activities for the period 1st April to 30th June 1973. De Beers Prospecting Botswana (Pty) Limited. p. 1.

MuRRAY, L.G. 1973d. Quarterly report, State Grant 7/72, Ngwaketsi District. Report on prospecting activities for the period 1st July to 30th June 1973. De Beers Prospecting Botswana (Pty) Limited. p. 1.

Prain, R. 1981. Reflections on an Era. Metal Bulletin Books, London. 262 p.

PRETORIUS, D.A. 1966. Conceptual geological models in the exploration for gold mineralisation in the Witwatersrand Basin. Information Circular no. 33. Economic Geology Research Unit, University of the Witwatersrand.

ReEves, C.V. and Hutchins, D.G. 1976. The national gravity survey of Botswana, 1972-3. Bulletin no. 5, Geological Survey of Botswana, Lobatse. 36 p.

TAYLoR III, A.L. 1982. A gem that lost its luster. Time Magazine. 30 August 1982. http://content.time.com/time/magazine/article/ 0,9171,921271,00.html

TERRA SuRveys Limited. 1978. Reconnaissance aeromagnetic survey of Botswana, 1975-1977. Botswana Geological Survey Department and Canadian International Development Agency. 199 p.

Webb, K., Stiefenhofer, J., and Field, M. 2003. Overview of the geology and emplacement of the Jwaneng DK2 Kimberlite, Southern Botswana. [Long abstract]. Proceedings of the 8th International Kimberlite Conference. Victoria, British Columbia, Canada, 22-27 June 2003. Mitchell, R.H. (ed.). Elsevier, Amsterdam.

WiLLIS, J.H.A. 1960. Final report on the Bechuanaland investigation. Central African Selection Trust Ltd. 